\title{
PARTIAL GASTRECTOMY ASSOCIATED TO ANTERIOR TRUNCAL VAGOTOMY: ALTERATIONS IN METABOLISM OF THE CALCIUM. EXPERIMENTAL STUDY IN RATS
}

\section{Gastrectomia parcial e vagotomia troncular anterior: alterações no metabolismo de cálcio. Estudo experimental em ratos}

\author{
Elisvânia Freitas dos SANTOS ${ }^{1}$, Kathia Hitomi TSUBOI ${ }^{1}$, Beatriz Frolini PALU ${ }^{1}$, Marina Rachel ARAÚJO ${ }^{2}$, \\ Nelson Adami ANDREOLLO ${ }^{2}$, Celio Kenji MIYASAKA ${ }^{1}$
}

ABCDDV/651

Santos EF, Tsuboi KH, Palu BF, Araújo MR, Andreollo NA, Miyasaka CK. Partial gastrectomy associated to anterior truncal vagotomy: alterations in metabolism of the calcium. Experimental study in rats. ABCD Arq Bras Cir Dig 2009;22(2):105-9

ABSTRACT - Background - The calcium is not absorbed in the lack of hydrochloric acid and the osteomalacia and osteoporosis may occurs; it is well recognized in patients that had gastric resection. Aim - To evaluate the effects of the partial gastrectomy associated to anterior truncal vagotomy in the absorption and metabolism of calcium. Methods - Eighteen adults male Wistar rats were submitted to partial gastrectomy associated to anterior truncal vagotomy (GXT, eight animals) and the sham operation (10 animals, control group). The diet consumption and the weight gains of the animals were measured three times during the week. The animals received formulated experimental diet orally (AIN-93M) by eight weeks. The serum calcium, urinary and fecal calcium, apparent absorption of the calcium, activity of the enzyme alkaline fosfatase and calcium in the bone were measured after 60 days. Results - The sham operated animals showed higher diet consumption, weight gains, serum and urinary calcium, excretion of calcium in feces, apparent absorption of calcium and activity of the enzyme alkaline fosfatase $(P<0,05)$ as compared to the animals of the gastrectomized group. However, the concentration of the bone calcium was increased in the animals of the gastrectomized group. Conclusion - Partial gastrectomy associated to anterior truncal vagotomy showed to be a good experimental model the study calcium metabolism, decreasing the calcium absorption, serum and urinary calcium and activity of the enzyme alkaline fosfatase. However, for alterations at bone level in rats suggests an experimental study in larger period.

HEADINGS - Gastrectomy. Calcium. Wistar rats.

\section{INTRODUCTION}

The partial or total gastrectomy is practically the main form of treatment of the gastric cancer ${ }^{6}$. In the partial gastrectomy the gastrointestinal transit is recovered through anastomosis with the duodenum (Billroth I - BI) or jejunum (Billroth II - BII). In the total gastrectomy the main reconstruction is Roux-em-Y esophagojejunum anastomosis. The partial or total gastrectomy leads to a decrease in the secretion of hydrochloric acid $(\mathrm{HCl})$ and of the intrinsic factor, reducing the digestive function of the stomach and the duodenum and the absorption processes are decreased ${ }^{7,13}$.

The calcium is not absorbed in the lack of hydrochloric acid and the osteomalacia and osteoporosis may occurs; it is well recognized in patients that had gastric resection ${ }^{15,23}$. Some studies demonstrated that the total gastrectomy in rats reduces notably the absorption of calcium no soluble and bone calcium ${ }^{5,12}$.

Trabalho realizado na Faculdade de Engenharia de Alimentos ${ }^{1}$ e Núcleo de Medicina e Cirurgia Experimental da Faculdade de Ciências Médicas ${ }^{2}$ da UNICAMP, Campinas,SP, Brasil.

Endereço para correspondência: Elisvânia Freitas dos Santos, e-mail: elisvania@gmail.com
This research has as objective to evaluate the effects of the partial gastrectomy associated to truncal anterior vagotomy in the metabolism of calcium in rats.

\section{METHODS}

The experimental protocol was approved by the Committee of Ethics in Animal Experimentation (CEEA) of the State University of Campinas - UNICAMP (certificate number 839-1, 08/06/2005).

Eight rats weighting $250 \mathrm{~g}$ were anesthetized (intravenous) with sodic thiopental ( $25 \mathrm{mg} /$ body weigth) and submitted to the gastrectomy Billroth II plus anterior truncal vagotomy. An end-lateral isoperistaltic gastroenteroanastomosis was performed with the jejunum for transit reconstruction.

The Sham operated group (10 animals) was submitted to the same surgical stress, where the abdominal cavity was maintained open for approximately 45 minutes, which it is the duration of a gastrectomy.

After 15 days of the procedure, the animals received the formulated experimental diet (Table 1) and denominated AIN-93M by eight weeks ${ }^{16}$. 
TABLE 1 - Composition of experimental diet

\begin{tabular}{ll}
\hline Ingredients & $\mathbf{g} / \mathbf{K g}$ \\
\hline Cornstarch 1 & 466 \\
Dextrinized cornstarch 1 & 155 \\
Casein 2 & 140 \\
Soybean oil 3 & 40 \\
Cellulose 4 & 50 \\
Sucrose 5 & 100 \\
Mineral mixture 6 & 35 \\
Vitamin mixture 6 & 10 \\
L-Cystine 7 & 1,8 \\
Choline bitartrate 8 & 2,5 \\
Tert-butylhydroquinone 8 & 0,008 \\
\hline
\end{tabular}

1 Cornstarch and dextrinized cornstarch (Corn Products Brasil - Ingredientes Industriais Ltda, Mogi Guacu, Sao Paulo, Brazil).

2 Plury Chemistry Ltda, Diadema, Sao Paulo, fabricate pela Naarden Agro Products-Holland. 3 Mark Liza, Cargill do Brazil, Uberlandia, Minas Gerais, Brazil.

4 Mark Microcel, Blanver Farmoquimica Ltda, Cotia, Sao Paulo, Brazil.

5 Refinaria Uniao, Assis, Sao Paulo, Brazil.

6 Prepared according to the AIN-93M formulation (REEVES; NIELSON; FAHEY JR, 1993). Formulate for M. Cassab Comercio e Industry Ltda, Sao Paulo-Sao Paulo, Brazil.

7 Mark Synth C1027.01.AE; Diadema, Sao Paulo, Brazil.

8 Sigma Chemical Co., St. Louis, Mo, USA.

The animals were maintained in collective cages at room with controlled temperature $\left(22 \pm 1^{\circ} \mathrm{C}\right)$, humidity $(60-70 \%)$, cycle of 12 hours day-night (lights on at 7:00 am), with diet and deionized water ad libitum. The weight gain and the consumption of the diet of the animals were monitored three times a week, during eight weeks.

After 60 days from the beginning of the diet, were measured apparent absorption of the calcium, serum calcium, urinary and fecal calcium, activity of the enzyme alkaline fosfatase and calcium in the bone.

The serum and urinary calcium contents were measured by a commercial colorimetric method (Kit Laborlab, Guarulhos, Sao Paulo, Brazil) using a Spectrophotometer Beckman $\mathrm{DU}^{\circledR}-70$ at $560 \mathrm{~nm}$.

The determinations of diet and fecal calcium were performed in an Optic Emission Spectrometer IRIS-AP (Thermo Jarrell Ash, Franklin - Massachusetts - USA) at the specialized Laboratory of Biominerals Chemical Analyses Ltda, Campinas, Sao Paulo, Brazil.

The collection of the feces of the animals, was performed in the metabolic cages at the15th, 35th and 55th days of the experimental phase, for a three days periods ${ }^{2,12}$.

The apparent absorption of the calcium was determined as followed: apparent absorption $(\mathrm{mg} /$ day $)=$ ingestion of calcium (mg/day) - excretion of fecal calcium (mg/day) ${ }^{20}$.

The determination of the termolabil bone alkaline fosfatase, was firstly measured as total alkaline fosfatase by colorimetric method (Kit Laborlab, Guarulhos, Sao Paulo, Brazil), at $405 \mathrm{~nm}$ using Spectrophotometer Beckman DU ${ }^{\circledR}$ - 70 with temperature control. The termolabil fraction inactived $\left(56^{\circ} \mathrm{C}\right.$ during 15 min., water bath Dubnoff Tecnal Model TE-053 - Tecnal ${ }^{\circledR}$ ), and the final result was obtained by the difference.

The determination of bone calcium was done in femur removed after the death of the animals, the muscle was removed and the femur was frozen. The bone was burned in muffle furnace (Fornitec Industria e Comercio Ltda, São Paulo, São Paulo, Brazil) at $600^{\circ} \mathrm{C}$ to the obtain clear ashes.
The determinations of bone calcium were performed in an Optic Emission Spectrometer IRIS-AP (Thermo Jarrell Ash, Franklin - Massachusetts - USA) at the specialized Laboratory of Biominerals Chemical Analyses Ltda, Campinas, São Paulo, Brazil.

For statistical analysis, the data are expressed as mean \pm standard error of the mean (SEM) and submitted to the variance analysis ANOVA $(P<0,05)^{12}$.

\section{RESULTS}

The consumption of the diet (g/day) (Figure 1) as well as the weight gains of the gastrectomized rats (GXT) (Figure $2)$ were reduced $(P<0,05)$.

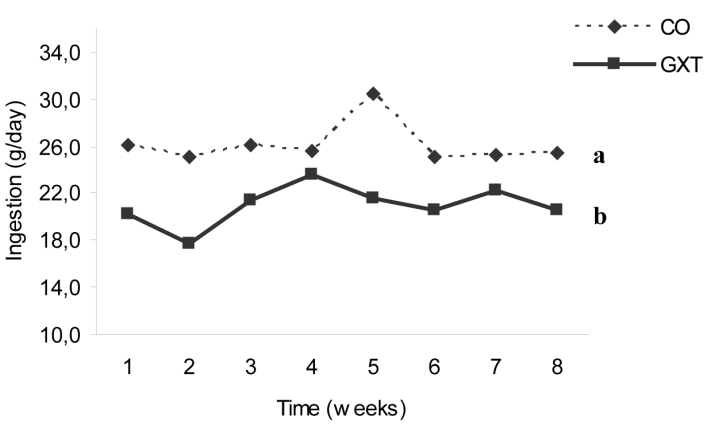

FIGURE 1 - Medium consumption of the oral diet (g/day); (CO: $\mathrm{n}=10$; GXT:n=8); (a versus b $P<0,05)$. For details of diet, see Table 1

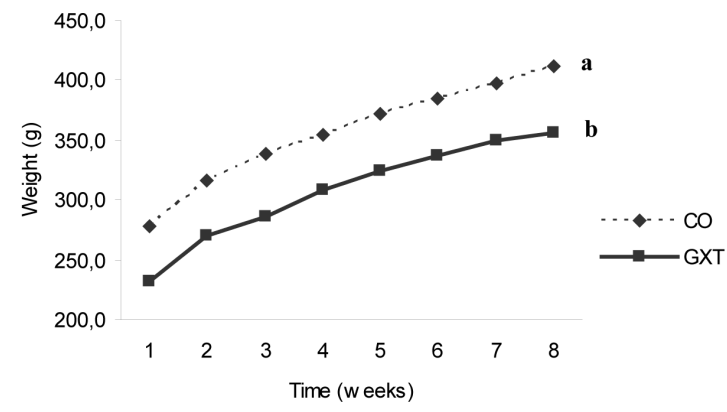

FIGURE 2 - Weight gains of the rats (g). (CO: n=10; GXT:n=8); (a versus b $P<0,05$ ).

The concentration of seric calcium $(\mathrm{CO}=7,20 \pm 0,34$; $\mathrm{GXT}=6,10 \pm 0,44 \mathrm{mg} / \mathrm{dL}$ ) in the animals of GXT group was reduced in $15,3 \%$ and urinary calcium $(\mathrm{CO}=134,11 \pm 9,27$; GXT $=94,68 \pm 9,62 \mathrm{mg} / 24 \mathrm{~h}$ ) of the GXT group was $29,4 \%$ lower as compared to the animals of the $\mathrm{CO}$ group (Figure 3 and Figure 4).

The excretion of calcium in feces of the GXT group was reduced in $6.4 \%(\mathrm{CO}=61,13 \pm 1,81 ; \mathrm{GXT}=57,21 \pm 2,23$ $\mathrm{mgCa} / \mathrm{g}$ of feces) as compared to the $\mathrm{CO}$ group (Figure 5).

The apparent absorption reduced in $41.0 \%(P<0,05)$ in the animals of the group GXT $(\mathrm{CO}=52,18 \pm 4,15$; $\mathrm{GXT}=30,76 \pm 5,87 \mathrm{mg} /$ day) as compared to the animals of the control group (CO) (Figure 6). 


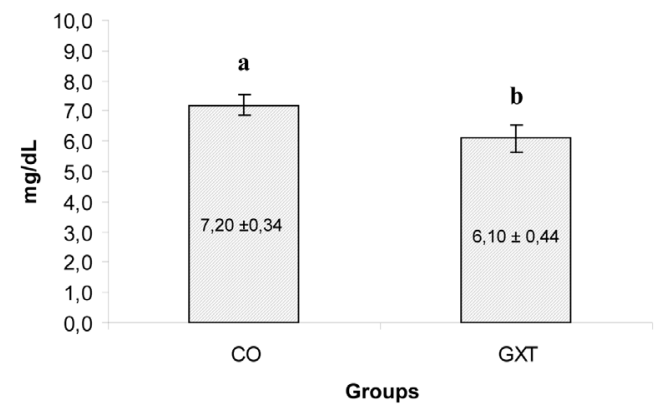

FIGURE 3 - Medium concentrations \pm EPM of serum calcium $(\mathrm{mg} / \mathrm{dL})(\mathrm{CO}: \mathrm{n}=10$; GXT:n=8); (a versus b $P<0,05)$.

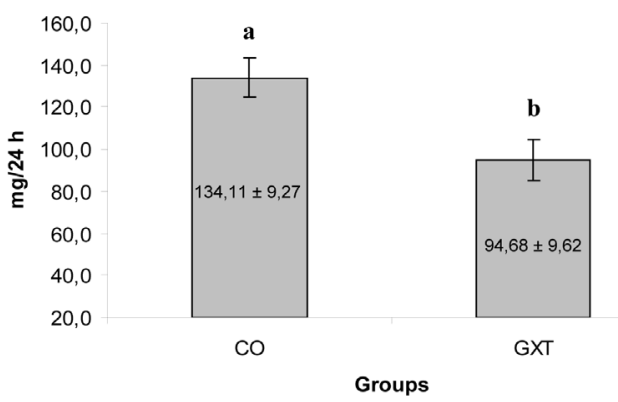

FIGURE 4 - Medium concentrations \pm EPM of urinary calcium $(\mathrm{mg} / 24 \mathrm{~h})(\mathrm{CO}: \mathrm{n}=10 ; \mathrm{GXT}: \mathrm{n}=8)$; (a versus b $P<0,05)$.

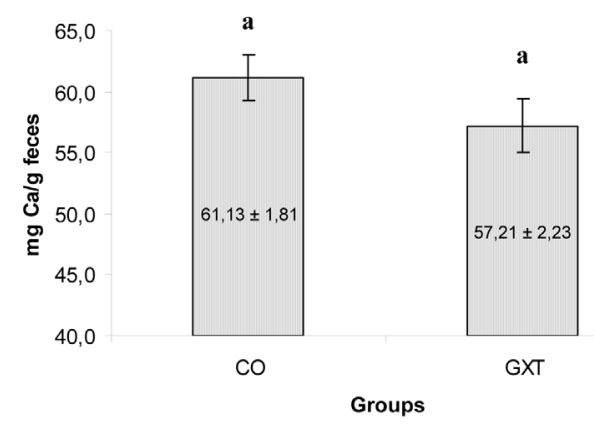

FIGURE 5 - Medium concentrations \pm EPM of calcium excreted in the feces (mg/g feces) (CO: $\mathrm{n}=10 ; \mathrm{GXT}: \mathrm{n}=8)$. (Duncan's test: $P<0,05$ ).

Gastrectomy reduced the activity (16.5\%) of the alkaline fosfatase $(\mathrm{CO}=134,61 \pm 8,78 ; \mathrm{GXT}=112,36 \pm 6,64$ $\mathrm{U} / \mathrm{L}$ ) (Figure 7). However the concentration of calcium in the bone in the animals of the group GXT increased (4.1\%) $(\mathrm{CO}=344,17 \pm 5,54 ; \mathrm{GXT}=358,98 \pm 3,87 \mathrm{mg} / \mathrm{g}$ of bone) as compared to the animals of the control group (CO) (Figure 8).

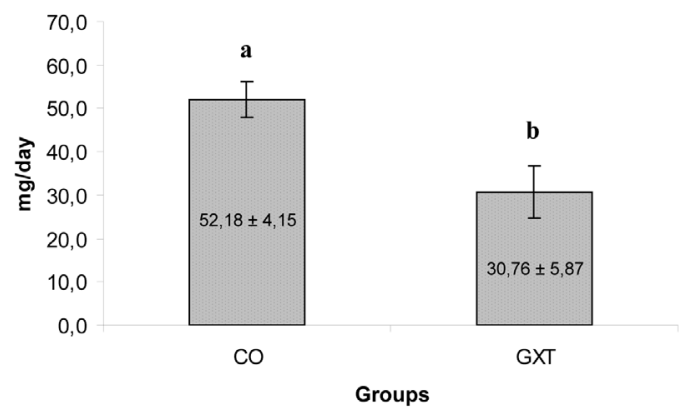

FIGURE 6 - Apparent absorption of the calcium (mg/day) \pm EPM (CO: n=10; GXT:n=8); (a versus b $P<0,05)$.

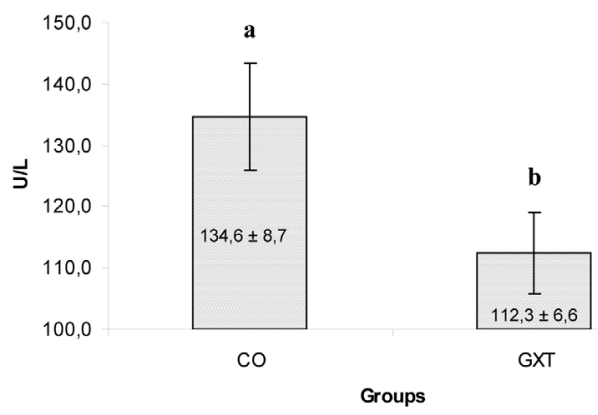

FIGURE 7 - Medium concentrations \pm EPM of the activity of the bone alkaline fosfatase $(\mathrm{U} / \mathrm{L})$ serum $(\mathrm{CO}: \mathrm{n}=10$; GXT:n=8). (a versus b $P<0,05$ ).

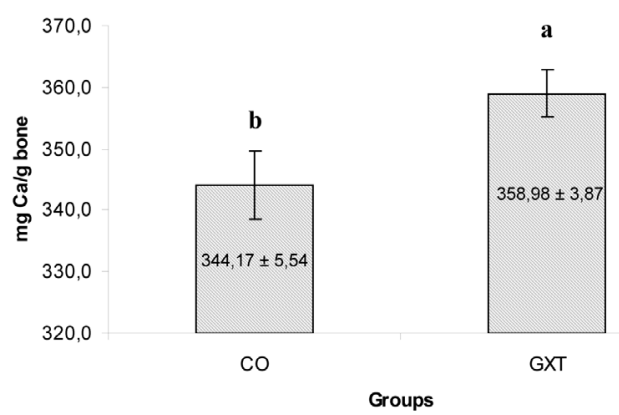

FIGURE 8 - Medium concentrations \pm EPM of bone calcium $(\mathrm{mg} / \mathrm{g}$ bone) $(\mathrm{CO}: \mathrm{n}=10 ; \mathrm{GXT}: \mathrm{n}=8)$. (a versus $\mathrm{b}$ $P<0,05)$.

\section{DISCUSSION}

The reduced weight gain in the GXT animals was also verified by Ohta et al. ${ }^{12}$.

The reduced seric calcium of the animals of the GXT group suggests that the gastrectomy reduces the absortion of the calcium. These results were also verified by Axelson et al. ${ }^{1}$. These authors afirm that this is a similar process 
in humans where the gastrectomy induces a progressive defiency in the absortion in the calcium. They also suggest that the gastric mucosa may have a calcium tropic agent, the gastrocalcin, which stimulates the calcium absortion by the bone. Sakai et al. ${ }^{17}$, also verified a reduced seric calcium in gastrectomized rats.

Zittel et al. ${ }^{23}$ also verified reduced calcium in humans with partial and total gastrectomy, suggesting that this is due to a reduced release of calcium from the foods, the increased intestinal flow and to the removal of duodenum and jejunum. The sum of these factors leads to a reduced seric calcium.

The urinary calcium is used to evaluate the renal ${ }^{17}$. The excretion of these mineral and is a good parameter to reach the balance between the absorption and the calcium lost from the bone ${ }^{22}$.

The urinary calcium of the animals of GXT group was reduced (29.4\%), this was also verified by Axelson et al. ${ }^{1}$, however in only $20 \%$. The reduced levels of calcium may be due to an increase tubular reabsorption when the seric calcium is reduced, an incresed levels of PTH was observed, increasing the tubular reabsoption. Morohashi et al. ${ }^{10}$ observed in gastrectomized rats an elevation of PTH, these was also verified by Zittel et al. ${ }^{23}$ in humans. Then, these may occur in our experiments.

The intestinal absorption of calcium results from the active transport mainly in the duodenum and upper jejunum and the passive difusion in the whole intestine, in the ileum and in the large intestine ${ }^{13}$.

The fecal excretion and the absorption of calcium was lower in the gastrectomized animals as compared to the control, this suggests that these experimental protocol really causes depletion in the absorption of the mineral calcium. Some other studies showed that the total gastrectomy in rats reduces the calcium absorption ${ }^{5,12}$. Zittel et al. ${ }^{23}$ verified in humans with partial gastric resection and total gastrectomy these reduced absorption, they suggest that is due to the reduced release of calcium of the foods by the impaired digestion, to an increased intestinal flow and to the removal of the duodenum and upper jejunum. These summed effects impairs the calcium absorption after the gastrectomy.

The activity of the bone alcaline phosphatase was lower in gastrectomized animals as compared to the control group. The activity of this enzime give us some information about the metabolism in the bone, where these increased activity indicates that process of formation of the bone is reduced. Zittel et al. ${ }^{23}$ demonstrated in humans that the acitvity of alcaline phosphatase showed alterations in the total gastrectomy. The BI or BII partial resections did not showed alteration in this enzyme ${ }^{23}$. In fact, this elevation may be due to an enhanced osteogenesis however it occurs also in the osteomalacia ${ }^{22}$.

This research demonstrates that the concentration of calcium in the bone was higher in gastrecmotized animals. The bone is the main storage site of calcium of the organism and the 60 days of depletion may be not enough to cause a sensitive reduction. After the gastric resection the content of calcium in the bone is reduced and became more pronounced during the time ${ }^{14}$. These results were observed in other studies ${ }^{5,12,15,19}$.

Some authors confirmed a correspondence of 30 days of the man's life to one day of life of the rat ${ }^{3,4,8,9}$.

\section{CONCLUSION}

The gastrectomized rat is a good experimental model for studies of the absorption of calcium, as only two months after the surgery were enough to modify statistically the metabolism in mineral calcium, however not changed the content of calcium in the bone.

\section{ACKNOWLEDGMENTS}

To National Council of Technological and Scientific Development (CNPq), Laboratory Biominerals Chemical Analyses Ltda and Johnson \& Johnson ${ }^{\circledR}$ for the surgical sutures.

Santos EF, Tsuboi KH, Palu BF, Araújo MR, Andreollo NA, Miyasaka CK. Gastrectomia parcial e vagotomia troncular anterior: alterações no metabolismo de cálcio. Estudo experimental em ratos. ABCD Arq Bras Cir Dig 2009;22(2):105-9

RESUMO - Racional - O cálcio não é absorvido na ausência de ácido clorídrico e a osteomalácia e osteoporose podem ocorrer; este fato é bem reconhecido em pacientes que se submeteram à gastrectomias. Objetivo - Avaliar os efeitos da gastrectomia parcial associada à vagotomia troncular anterior na absorção e metabolismo de cálcio. Métodos - Dezoito ratos Wistar machos e adultos foram submetidos à gastrectomia parcial e vagotomia troncular anterior (oito animais) e à laparotomia simples como grupo controle (10 animais). O consumo de dieta e o peso dos animais foram monitorados três vezes por semana. Os animais receberam dieta oral formulada experimentalmente (AIN-93M), durante 8 semanas. O cálcio sérico, cálcio urinário e fecal, absorção aparente de cálcio, atividade da enzima fosfatase alcalina e cálcio ósseo foram mensurados após 60 dias de observação. Resultados - Os animais controle apresentaram médias estatísticas maiores $(P<0.05)$ para o consumo de dieta, ganho de peso, cálcio sérico, cálcio urinário, excreção de cálcio nas fezes, absorção aparente de cálcio e atividade da enzima fosfatase alcalina comparados aos animais do grupo gastrectomizado. Entretanto, a concentração de cálcio ósseo foi superior no grupo de animais gastrectomizados $(P<0,05)$ quando comparado com o grupo controle. Conclusão - A gastrectomia parcial associada à vagotomia troncular anterior mostrou ser um bom modelo experimental para estudo com o metabolismo de cálcio, ocasionando diminuição da absorção de cálcio, cálcio sérico, cálcio urinário e fosfatase alcalina. No entanto, para alterações a nível ósseo em ratos, sugere-se um estudo experimental em período maior.

DESCRITORES - Gastrectomia. Cálcio. Ratos Wistar. 


\section{REFERENCES}

1. Axelson J, Persson P, Gagnemo-Persson R, Hakanson R. Importance of the stomach in maintaining calcium homoeostasis in the rat. Gut 1991;32(11):1298-302.

2. Chonan O. \& Watanuki M. The effect of 6'-Galactooligosaccharides on bone mineralization of rats adapted to different leves of dietary calcium. Int J Vitam Nutr Res. 2003;66(3):244-49.

3. Donaldson HH. The rat. 2.ed. Philadelphia, 1924.

4. Gittes RF. Carcinogenesis in ureterosigmoidostomy. Urol Clin North Am. 1986;13(2):201-05.

5. H, Suzuki T, Aoyama Y. La ingesta de fibras dietarias solubles, polidextrosa, incrementa la absorción de cálcio y la mineralización ósea em ratas normales y gastrectomizadas. Br J Nutr 2000;84:655-61.

6. Inca - Instituto Nacional do Câncer, 2008. Disponível no site: $<<$ http://www. inca.gov.br $>>$ Acesso 10/07/2008.

7. Jacob CE, Gama-Rodrigues JJ, Irya K, Bresciani CJC, Zilberstein B, Martins $\mathrm{BC}$, Cecconello I. Câncer gástrico precoce: complicações e mortalidade após gastrectomia e linfadenectomia regrada - experiência com 178 casos em uma instituição. ABCD Arq Bras Cir Dig 2006; 19(4): 146-152

8. Júnior DI, Nigro AT, Sementilli A, Juliano Y, Novo NF. Comparação das anastomoses esôfago-gástricas término-terminais em plano único e por invaginação de submucosa e mucosa em ratos. Acta Cir Bras. 2000;15(1):35.

9. Klee LW, Hoover M, Mitchell ME, Rink RC. Long term effects of gastrocystoplasty in rats. J Urol. 1990;144(5):1283-87.

10. Morohashi T, Hirama Y, Takahara S, Sano T, Saitoh S, Ohta A, Sasa R, Yamada $\mathrm{S}$. Defects in mandibular bone area, enamel iron content and dentine formation following gastrectomy in rats. Arch Oral Biol 2002;47(6):499-504.

11. Ohta A, Ohtsuki M, Hosono A, Adachi T, Hara H, Sakata T. Dietary fructooligosaccharides prevent osteopenia after gastrectomy in rats. J Nut 1998;128(1)106-10.

12. Ohta A, Ohtsuki M, Uehara M, Hosono A, Hirayama M, Adachi T, Hara H. () Dietary fructooligosaccharides prevent postgastrectomy anemia and osteopenia in rats. J Nut 1998;128(3):485-90.
13. Pansu D, Bronner F. Nutritional aspects of calcium absorption. J Nut 1999;129(1): 9-12.

14. Papini-Berto SJ \& Burini RC. Causas da desnutrição pós-gastrectomia. Arq Gastroenterol 2001;38(4):272-75.

15. Prisco C, Levine $\mathrm{SN}$. Metabolic bone disease after gastric bypass surgery for obesity. Am J Med Sci 2005;2(329):57-61.

16. Reeves PG, Nielson FH, Fahey GCJR. AIN-93 purified diets for laboratory rodents: final report of the American Institute of Nutrition ad hoc writing committee on the reformulation of the AIN-76A rodent diet. J Nut 1993;123(11):1939-51.

17. Sakai K, Aramaki K, Takasaki M, Inaba H, Tokunaga T, OHTA A. Effect of dietary short-chain fructooligosaccharides on the cecal microflora in gastrectomized rats. Biosci Biotechnol Biochem 2001;65(2):264-69.

18. Saraiva GL, Lazaretti-Castro M. Marcadores bioquímicos da remodelação óssea na prática cínica. Arq Bras Endocrinol Metabol 2002; 46(1):1-7.

19. Scholmerich J. Postgastrectomy syndromes - diagnosis and treatment. Res Clin Gastroenterol 2004; 18(5):917-33

20. Shiga K, Hara H, Okano G. \& Aoyama Y. () Ingestion of water-soluble soybean fiber prevents gastrectomy-induced iron malabsorption, anemia and impairment of voluntary running exercise performance in rats. J Nut 2003;133(4):1120-26.

21. Statsoft, Inc. Statistica for Windows [Computer program manual]. Tulsa, USA, 2000. WEB:http://www.statsoft.com.

22. Vieira JGHV. Exames e métodos laboratoriais relacionados com o metabolismo ósseo. In: Manual de doenças ósteo-metabólicas. Campinas: Instituto Fleury: 2005.

23. Zittel TT, Zeeb B, Maier GW, Kaiser GW, Zwirner M, Liebich H, Starlinger M, Becker HD. High prevalence of bone disorders after gastrectomy. Am J Surg 1997;174:431-38.

Fonte de financiamento: não há Conflito de interesse: não há Recebido para publicação: 02/02/2009 Aceito para publicação: 28/03/2009 